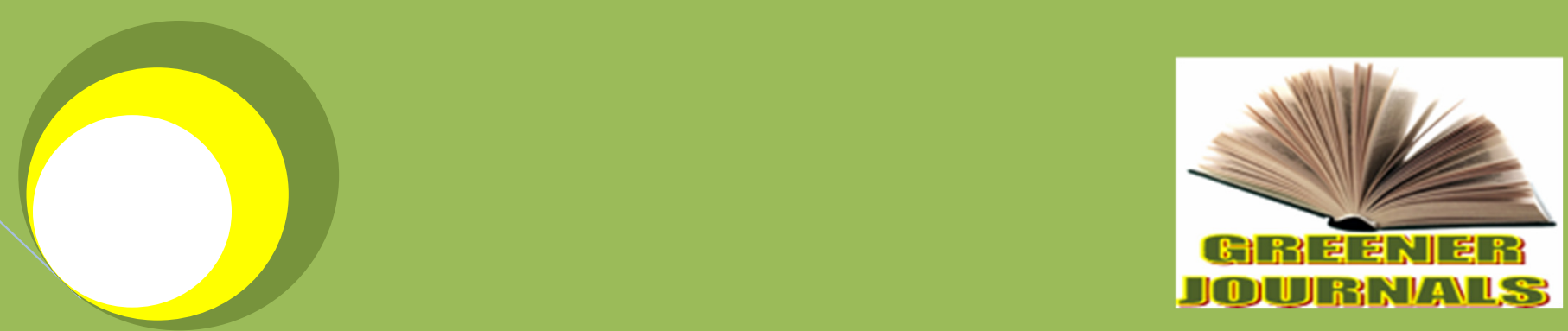

Greener.Jounal of Microbiology and Antimicrobials

ISSN: 2354-2284

Submitted: $24 / 12 / 2016$

Accepted: 30/12/2016

Published: 30/05/2017

DOI: http://doi.org/10.15580/GJMA.2017.2.122416220

Bacteriological

Quality Assessment of

Indoor Air of Science

Laboratories in Ramat

Polytechnic,

Maiduguri Borno State

By

A.M. Bukar

A. Digima

A. Bwala

F.S. Kuburi

F.K. Ibrahim 


\title{
Bacteriological Quality Assessment of Indoor Air of Science Laboratories in Ramat Polytechnic, Maiduguri Borno State
}

\author{
Bukar A.M. ${ }^{1 *}$, Digima A. ${ }^{2}$, Bwala A. ${ }^{3}$, Kuburi F.S. ${ }^{4}$ and Ibrahim F.K. ${ }^{5}$ \\ 1,2,3,4,5 Department of Science Laboratory Technology, Ramat Polytechnic, Maiduguri-Borno state. \\ *Corresponding Author's Email: alhmodubuk@ gmail.com
}

\begin{abstract}
A study on indoor airborne bacteriological contamination in various laboratories of Science Laboratory Technology in Ramat Polytechnic Maiduguri, Borno state, is presented. The present study is aimed at determination of indoor-air bacteriological contamination of SLT laboratories. Investigations were conducted in March, 2016. Air samples were taken twice a day: in the morning (10am) and in the afternoon $(4 \mathrm{pm})$. Total numbers of mesophilic aerobic bacteria count (ranged between $1.0 \times 10^{2}-5.3 \times 10^{2} \mathrm{cfu} / \mathrm{m}^{3}$ ) from the air of selected laboratories were determined using Koch sedimentation method. This was determined through sampling using "Settled Plate Technique (SPT)", Petri plates filled with nutrient agar was used in the sample collection. In all of the tested places a multiple growth of bacteria were observed in afternoons than in the morning hours. The predominant bacteria isolated from investigated air samples were: Escherichia coli 24(41.37\%), Klebsellia pneumonia 7(12.07), Shigella spp 9 (15.52), and Staphylococcus spp 18 (31.03). Among these bacterial isolates the presence of pathogenic and strongly allergenic microorganisms was detected. The current study clearly indicates that there is significant assessment of the indoor airborne bacteria.
\end{abstract}

Keywords: Indoor air, bacteriological quality, airborne bacteria, open plate technique

\section{INTRODUCTION}

The term Indoor Air Quality (IAQ) is refers to the air quality within and around buildings and structures, especially as it relates to the human health and comfort of building occupants (Prescott et al., 1999). IAQ can be affected by microbial contaminants (mold, bacteria), or any mass or energy stressor that can induce adverse health conditions (WHO, 2009). Source control, filtration and the use of ventilation to dilute contaminants are the primary methods for improving indoor air quality in most buildings. Residential units can further improve indoor air quality by routine cleaning of carpets and area rugs (Kalwasinska et al., 2012).

However, bacteria are present on all inanimate surfaces creating ubiquitous sources of possible contamination in the laboratory. Experimental success relies on the ability of a scientist to sterilize work surfaces and equipment as well as prevent contact of sterile instruments and solutions with non-sterile surfaces. Nonetheless, many of these microorganisms are present in the air on minute dust particles, which can remain suspended for long periods, but they may also be dispersed in the very small water droplets of aerosols. Aerosols can be produced from people, through coughing and sneezing, and by many other mechanisms (The World Book Encyclopedia of Science, 1994).

Nevertheless, clean air is a basic requirement of life. The quality of air inside houses, offices, schools, public buildings, health care facilities or other private and public buildings where people spend over $90 \%$ of their lives indoors, where they are exposed to some indoor environmental factors (bioaerosol) that influence their health and physical condition (Abdel Hameed and Farag, 1999). Therefore there has been a growing interest in indoor microbial studies in recent years is an essential determinant of healthy life and people's well-being (Ekhaise et al., 2010)

The present study is therefore aimed at assessing the airborne bacteria present in the indoor laboratory environment that could possibly cause contamination of culture media and infection of laboratory personals and students as they often make use of the laboratory. 


\section{MATERIALS AND METHODS}

\section{Study Area}

Ramat Polytechnic, Maiduguri is a public higher educational institution established in January 1973 as Government Technical College by the defunct North-Eastern State Government. The Technical College was upgraded and renamed Ramat College of Technology in April 1978 by the then Borno State Government to Immortalize the name of the late Head of State, General Murtala Ramat Muhammad. In august 1979, it was again upgraded to the status of a Polytechnic in conformity with the Federal Government initiative to rename all Colleges of Technology in the country to Polytechnic. Ramat Polytechnic, which started by admitting only three hundred students in 1978 has a student population of over fourteen thousand students as at 2013/2014 Academic Session. So far, about forty thousand students have graduated from the Institution with National Diploma, Higher National Diploma, National Certificate in Education in Technical and Business, and Polytechnic Diploma, Certificate and AEO. The study was conducted March, 2016.

\section{Sample collection/ Sampling procedure}

Passive monitoring typically employs 'settle plates' also known as sedimentation method was used as sample collection method. In this technique, standard $90 \mathrm{~mm}$ diameter petri dishes containing sterile culture media (Nutrient Agar, Blood Agar and MacConkey Agar) were opened and exposed at the six (6) SLT laboratories 15 mins. After which the Petri dishes containing nutrient agar were closed and placed in the incubator at $37^{\circ} \mathrm{C}$ for possible bacterial growth within 18 to 24 hours (Cheesbrough, 1991).

A total number of 15 plates were exposed at each exposure time; these comprised of 6 Nutrient agar plates (2 in Biology/Microbiology laboratories, 2 in Chemistry laboratories and 1 Physics laboratory, the same number of Blood agar and MacConkey agar plates were used. Thus, this was carried out 2 times in a day (10 am - when the number of students and staff present are minimal and $4 \mathrm{pm}$ - when the day's work is done and students and staff are about leaving the laboratory). The total number of individuals present in the different laboratory at each time of exposure was noted (Baker et al., 2001). All samples were taken in September (before the beginning of the academic year) and October (during academic year). Isolates were identified by their cultural characteristics, morphological appearance and biochemical characteristics as described by many researchers (Koneman et al., 1997). Colony forming unit (CFU) of the bioaerosols (bacteria) were assessed (2 times a day) for three days, taking into consideration the number of individuals present at each exposure time at the sampling sites and the weather conditions at such points.

\section{RESULTS}

Table 1: Number of bacterial $\mathrm{CFU} / \mathrm{m}^{3}$ air at different sampling time of day at different time of exposure

\begin{tabular}{lllll}
\hline $\begin{array}{l}\text { Investigated } \\
\text { rooms }\end{array}$ & $\begin{array}{l}\text { Time of taking } \\
\text { samples }\end{array}$ & \multicolumn{3}{l}{$\begin{array}{l}\text { Total number } \\
\text { of bacteria } \\
{\left[\mathrm{cfu}^{3} \mathrm{~m}^{3}\right.}\end{array}$} \\
& & Day & Day 3 \\
\cline { 3 - 5 } & Day 1 & $3.1 \times 10^{2}$ & $4.7 \times 10^{2}$ \\
\hline New Bio. Lab. & Morning & $2.7 \times 10^{2}$ & $3.7 \times 10^{2}$ & $5.3 \times 10^{2}$ \\
& Afternoon & $3.3 \times 10^{2}$ & $1.1 \times 10^{2}$ & $1.7 \times 10^{2}$ \\
Old Bio. Lab. & Morning & $3.5 \times 10^{2}$ & $2.5 \times 10^{2}$ & $2.3 \times 10^{2}$ \\
& Afternoon & $4.3 \times 10^{2}$ & $1.0 \times 10^{2}$ & $2.0 \times 10^{2}$ \\
New Chem. Lab & Morning & $1.1 \times 10^{2}$ & $1.5 \times 10^{2}$ & $2.3 \times 10^{2}$ \\
& Afternoon & $1.3 \times 10^{2}$ & $1.3 \times 10^{2}$ & $1.0 \times 10^{2}$ \\
Old Chem. Lab. & Morning & $1.0 \times 10^{2}$ & $2.0 \times 10^{2}$ & $1.3 \times 10^{2}$ \\
\multirow{2}{*}{ Physics Lab. } & Afternoon & $2.1 \times 10^{2}$ & $1.0 \times 10^{2}$ & $2.0 \times 10^{2}$ \\
& Morning & $1.0 \times 10^{2}$ & $1.5 \times 10^{2}$ & $2.3 \times 10^{2}$ \\
\hline
\end{tabular}


Table 2: Percentage frequency of bacterial isolates from five laboratories analyzed

\begin{tabular}{ll}
\hline Type of Bacterial isolates & Percentage frequencies (\%) \\
\hline Escherichia coli & $24(41.37)$ \\
Klebsellia pneumonia & $7(12.07)$ \\
Shigella spp & $9(15.52)$ \\
Staphylococcus spp & $18(31.03)$ \\
Total & $58(100)$ \\
\hline
\end{tabular}

\section{DISCUSSION}

Bacteriological quality assessment of indoor air study is one of the most vital investigations to determine the microbial indoor air contamination. The information on the indoor microbial concentrations of airborne bacteria is necessary both to estimate the health hazard and to create standards for indoor air quality control. The concentrations of bacteria aerosols in the indoor environment of Science laboratories, estimated with the use of the settle plate method, ranged between $1.0 \times 10^{2}-5.3 \times 10^{2} \mathrm{cfu} / \mathrm{m}^{3}$

The average level of microbiological air contamination inside investigated university rooms is shown in Table 1. The number of bacteria in indoor air of the five SLT laboratories varied greatly in the whole research period. The total number of mesophilic aerobic bacteria in Day 1 ranged from $1.0 \times 10^{2}$ to $1.5 \times 10^{2} \mathrm{cfu} / \mathrm{m} 3$, in Day 2 it varied from $1.0 \times 10^{2}$ to $3.7 \times 10^{2} \mathrm{cfu} / \mathrm{m} 3$ and that of Day $1.0 \times 10^{2}$ to $5.3 \times 10^{2} \mathrm{cfu} / \mathrm{m} 3$, respectively.

The study showed that out of total 58 bacterial isolates obtained in the study, Escherichia coli has the highest occurrence 24(41.37) followed by Staphylococcus spp18 (31.03), Shigella spp 9 (15.52), and Klebsellia pneumonia 7 (12.07) has the least. These isolates are commonly found bio aerosols and pathogens in the air. This is because the carriers are commonly present in the area under study. This supports previous studies which state that Staphylococcus sp is the frequently commonly found pathogen in air (Kalwasinska et al., 2012).

The new Biology/Microbiology Laboratory had a higher meosophlic bacterial count. This could probably be attributed to the more number of students usually present in Microbiology Laboratory and their various research works, which could introduce more organisms to the indoor air.

In Conclusion, almost all the laboratories of Science Laboratory Technology were contaminated with both gram positive and gram negative bacteria. Thus, attention must be given to control those environmental factors which favor the growth and multiplication of such bacteria in indoor environment of laboratories to safeguard health of students and laboratory technicians and technologists. And also it needs to increase the size and the number of laboratories in Ramat Polytechnic, Maiduguri, so as to make them sufficient for the current and future student population.

\section{REFERENCES}

Abdel Hameed A.A., Farag S.A. (1999). An indoor bio-contaminants air quality. International Journal of Environmental Health Research 9, 313.

Baker, F.J., Silverton, R.J. \& Pallister, C.J. (2001). Medical Mycology. Introduction to Medical Laboratory Technology. (7th ed.), Bounty Press Ltd. 316 - 318Pp.

Cheesbrough, M. (1991). Medical laboratory manual for tropical countries. 2nd ed. Cambridge, UK: University Press Cambridge; pp. 508-511.

Ekhaise, F.O., Isitor, E.E., Idehen, O. and Emogbene, O.A. (2010). Airborne microflora in the atmosphere of an hospital environment of University of Benin Teaching Hospital(UBTH), Benin City, Nigeria. World Journal of Agricultural Science 6: 166-170.

Emojevwe V, Okeremeta O, Loveth, i. (2013) Aerial microbiology of the science building (ofrima complex) in the university of Port Harcourt. Advances in Agriculture, Sciences and Engineering Research 3: 809-815

Kalwasinska A, Burkowska A, Wilk I (2012). Microbial air contamination in indoor environment of the University Library. Aerosol and Air Quality Research 19: 25-29.

The World Book Encyclopedia of Science (1994). A World Book Inc, Chicago. Pp 28-29.

Koneman, E. W., Allen, S. D., Janda, W. M. \& Schreckenberger, P.C. (1997). Mycology. In Color Atlas and Textbook of Diagnostic Microbiology. ( $5^{\text {th }}$ ed.), 983-1057. Philadelphia, PA: Lippincott Williams \& Wilkins, USA.

Prescott, L. M., Harley, J. P. \& Klein, D. A. (1999). Microbiology.3rd edition W.m.C.Brown publisher's pp.147-151 
World Health Organization (2009). WHO guidelines for indoor air quality: dampness and mould. Copenhagen, Denmark: World Health [Online] Organization. Available from:http://www.euro.who.int/data/assets/pdf file/0017/43325/E92645.pdf. [Accessed on 24th November, 2013].

Cite this Article: Bukar AM, Digima A, Bwala A, Kuburi FS and Ibrahim FK, 2017. Bacteriological Quality Assessment of Indoor Air of Science Laboratories in Ramat Polytechnic, Maiduguri Borno State. Greener Journal of Microbiology and Antimicrobials, 3 (2): 018-021. http://doi.org/10.15580/GJMA.2017.2.122416220 